\title{
Content Analysis of \\ Female Athlete Endorsers in \\ UK Sports Magazine Advertisements.
}

\author{
Emmanuel Mogaji \\ University of Greenwich, London, UK \\ e.o.mogaji@greenwich.ac.uk
}

\begin{abstract}
Despite an increased level of females' participation in sports, the media coverage is still very low and inadvertently the use of female athletes as product endorsers has received limited attention. The purpose of this study is to provide an empirical insight into the frequency and nature of portrayals of female athlete endorsers in UK Sports Magazine by replicating Grau et al (2007)'s earlier study carried out in USA over ten years ago. Results of the content analysis indicate that females are seldomly featured as brand endorsers, female in team sports and from black ethnic minority group are less likely to be featured as brand endorsers. The study offers theoretical knowledge and practical implication for managers to ensure female athletes are well positioned and given the opportunity to be commercially viable.
\end{abstract}

Keywords: Women in Sport, Portrayal, Advertisement, UK, Content Analysis, Magazine

Cite as: Mogaji, E., 2019. Content Analysis of Female Athlete Endorsers in UK Sports Magazine Advertisements. Research Agenda Working Papers. Vol 2019 pp 55-73 


\section{Introduction}

Advertisements are considered a reflection of the inherent beliefs, cultural and societal values of a society and it further makes a major contribution to shaping these values and attitudes (Mogaji, 2015). Advertisers uses influential people within the society to transfer cultural meaning from their brands to individual consumer (McCracken, 1989). The selection of these influential people is of great importance as they should be able to effectively transfer the embedded cultural meanings to the benefit of the advertisers, however this can also be problematic the advertisements are created by people who aim to seek out relevant messages to appeal to their target audience (Gram, 2014).

Often advertisers use athletes, because of their influence and popularity within the society, as an endorser for their products and to reach out to their consumers. Sports personalities are considered as vehicles for advertisements or product endorsements and they carry symbolic messages can attract companies seeking effective endorsers (Mogaji, 2015b). Athletes carry very strong images, have a mass international audience, and appeal to all classes (Gwinner \& Swanson, 2003). Nike sponsors Lebron James and Cristiano Ronaldo to be its brand ambassadors, whereas Adidas sponsors James Harden and Leo Messi to promote its products and brand to its target consumers. The established brand value of the athlete will help his/her post-athletic career; well-branded athletes can leverage their brand value through their post-athletic careers (Irving et al, 2006). Sportsmen are more often chosen to become brand ambassadors because they are generally of a higher profile and attract a larger audience, which can increase the profit margins of the brands they endorse.

For the first time ever, Forbes' list of the 100 top-earning athletes of 2018 contains no women. This list is an annual rich list of athletes around the world and consists of their earnings from endorsements, prize money, salaries and bonuses, and appearance fees. Evidently, sports personalities are considered vehicles for advertisements or product endorsements (Arai, Ko and Ross, 2013), and athletes who promote symbolic messages can attract companies seeking effective endorsers. This raises questions about the prospect of sportswomen and their commercial viability as brand ambassadors during and after their careers. Even though the number of women participating in sports has increased over the years. However, the endorsement opportunities for sportswomen has not reflected such progress (Cooky, Messner, \& Hextrum, 2013; Lumpkin, 2009; Kian, Vincent, \& Mondello, 2008), this study aims to empirically provide insight into frequency and nature of portrayals of female athlete endorsers.

This is achieved by replicating Grau et al (2007)'s study on female athlete endorsers in the United States' magazine advertisements, to establish in UK context and over ten years if there has been an improvement in opportunities for female athletes. While Grau et al (2007) focused on different magazines, this present study specifically focused on sports magazine, with the aim of examining the frequency and nature of portrayals of 
female athlete endorsers. The frequency and nature of portrayals of male athlete endorsers will be used as a basis for comparison - to establish how frequently female athletes are portrayed as product endorsers in magazine advertising, are those female athletes portrayed from individual sports or team sports, if they are depicted in ways that highlight their athletic ability or their beauty and sex appeal and if they dressed in a suggestive manner or otherwise.

By examining this phenomenon from a marketing and advertising standpoint, there are clear implications for advertisers and the consuming public in understanding the portrayal and opportunities offered to female athletes in endorsing products. This study aims to add to our knowledge of how media (in this case, a print magazine advertisements) portrays female athletes. This knowledge will be useful for brand managers, sports' talent manager and researchers with interest in commercial viability of female athletes through brand endorsements.

\section{Literature Review}

Women have been known to participate in sport which is still considered a man's domain in the eyes of the media (Mogaji, 2015). The implications of this on the athletics, their brands, prospect and commercial value is also considered. Pfister (2010) noted that the lack of interest in women's football suggests why sponsors take little interest in the sport, which, in turn, has an adverse effect on the game and its development. It is as if the media is not creating awareness of females in sports, and, therefore, the general public may unfortunately not be as aware of women's sports as mass media exposure and coverage of a team or event have a strong influence on public image and opinions (Nichols et al., 2002; Pedersen et al., 2007) and commercially, advertisers may not be able to tap into their brands to endorse their products or services to stand out amidst the clutter of advertisements.

As the symbiotic relationship between sports and media has been established, James (2011) argued that it has become an important advertising platform for many brands to reach out to the consumers, suggesting it has become a prevalent platform for advertising "as it carries very strong images, has a mass international audience, and appeals to all classes" (Gwinner \& Swanson, 2003, p. 275). Kropp, Lavack, Holden, \& Dalakas, 1999 , p. 49) has also highlighted the "flexibility, broader reach, and higher levels of brand or corporate exposure" that sport platforms can offer. Arai, Ko and Ross (2013) noted that sport personalities are considered as vehicles for advertisements or product endorsement, and athletes who carry symbolic messages can attract companies seeking effective endorsers. Furthermore, the established brand value of the athlete will help his/her post-athletic career because well-branded athletes can leverage their brand value through their post-athletic career (Rein et al., 2006a). 
Though Thomson (2006) broadly defined the human brand as "any well-known persona who is the subject of marketing communications efforts" (p.104), Till (2001) suggested that only sport personality athletes who have earned a significant amount of money from endorsement contracts can be considered as brands, which sheds more light on the amount of awareness created for female sports to enhance their publicity and the image to make them attractive for prospective brands. Van Riper \& Badenhausen (2008) also noted that female athletes are likely to earn less money through endorsements, as they chosen less often to serve as endorsers than their male counterparts.

In finding out that women are less likely to commercially endorse a brand and also the idea that sport has been unfortunately tagged as a 'man's domain' and those interested in sports are more likely to be men, advertisements featuring in this media are more likely to be targeted towards men who are the main players and spectators of sports. Pfister (2010) also noted that the sexual portrayal of women in sports simply arouses greater attention and excitement, citing the example of volleyball players being photographed with bare bosoms which, in turn, generated public attention and seems to guarantee financial success for the media.

In addition, as consumers get exposed to advertisements while attending sporting events, on media and news coverage, an "excitement" and "emotional attachment" among consumers is suggested (Copeland, Frisby \& McCarville, 1996, p. 33) which allows the consumers to associate sports with a particular set of advertisements and brands. As James (2011) further suggested, those with a positive attitude toward sport are more likely to indicate more positive attitudes toward advertising.

According to Bem's (1981) gender schema theory, which was also adopted by Grau et al (2007) suggests that individuals tend to encode and organize incoming information in terms of a gender schema, and not surprised that sports is considered a man's activities and women has a different role to play. Heilman (2001) who suggested that engaging in sports that are considered not suitable with one's gender role typically results in unfavourable evaluations from others and because sports is considered as a male domain, females athletes are violating traditional gender roles and are subject to more negative evaluations.

Therefore, despite the increasing numbers of female participants in sports (Grau et al, 2007), it is postulated that there has not been a commiserate increase in female endorsements. Therefore, the following is expected:

HI: There are significantly more male athletes endorsing products in magazine advertising compared to female athletes.

Sport is still considered viewed as a predominantly a man's world (Mogaji, 2018), generally viewed as masculine and, therefore, more "naturally" appropriate for men than women (Messner, 2009, Hardin \& Greer, 2009; Koivula, 1995; Metheny, 1965). Matteo 
(1986) developed three classifications of sports taking into consideration the level of appropriateness and gender: male appropriate (e.g. basketball, soccer, football); female appropriate (e.g. gymnastics, figure skating, ballet), and neutral (e.g. golf, softball, tennis).

Pfister (2010) argued that common beliefs about sport suitability and gender exist in society, and 'it has always been taken for granted, for example, that men play American football and that women are keen gymnasts and dancers' (234), suggesting that some sports are more appropriate for males than females. For example, Camilla (1996) identified the deconstruction of gender and the redefinition of 'doing gender', suggesting that bodybuilding or boxing, are traditionally associated with masculinity and defined as being male sports.

Metheny (1965) presented the earliest analysis of gender stereotypes of different sports and it was reported that some sports such as figure skating, gymnastics, and synchronized swimming were deemed to be more appropriate for women than men, as they were aesthetically pleasing and prohibited bodily contact. She further argued that females who participated in more traditionally feminine sports (e.g., golf, tennis) are considered higher amongst their peers than those participating in more traditionally masculine sports. Consistent with the little attention given to team sports and focus on individual sports, the following is expected:

H2: Female athletes appearing as endorsers are more likely to be from an individual sport compared to team sport while male athletes chosen for endorsements are more likely to be from a team sport compared to an individual sport.

Goffman (1974) considered framing as a prominent theory in analysing manners in which the media package their content for public consumption. They 'organise issues, pointing both backward at what happened and forward, offering interpretive cues for what it all means' (Boykoff and Laschever 2011, 346). In addition, the social role theory is also considered applicable to this present study as it further exploits the role of women in the society and, in particular, sports. The theory was developed by Eagly (1987), which suggested there are expectations regarding the roles men and women occupy as well as traits and behavioural propensities believed to be desirable for each gender. Franke, Crown and Spake (1997) considered the theory an influential structural account of gender differences. It has also been shown that people generally believe men and women possess different characteristics, and that these differences are hard-wired rather than socially constructed (Eagly, Wood, \& Johanssesen-Schmidt, 2004).

This theory suggested that women are general considered as more communal ("friendly, unselfish, concerned with others and emotionally expressive"), whereas men are more agentic ("independent, masterful, assertive, and instrumentally competent"; Eagly \& 
Wood, 1991, p. 309). This can also be said of sports as earlier indicated that some sports are considered traditionally feminine, while others are masculine. Koivula (2001, p. 377) suggested that, "labelling of different activities as feminine and masculine is largely a social construction based on stereotyped expectations regarding gender and perceived gender differences". This idea is also reflected in sports, as some are deemed appropriate for boys (masculine), while others are appropriate for girls (feminine) or for both genders (neutral) (Koivula, 1995, 2001; Matteo, 1986).

As previous research has suggested that physical attractiveness of the endorser can be an advantage in some product categories (Bower and Landreth 2001). Additionally, the traditional views of female roles in society may compromise the level of expertise some consumers associate with female athlete endorsers based on their athletic prowess alone. Female athletes, then, go against the sex-typed gender schemas, which are wellingrained, the female athletes are portrayed first as a woman and second as athlete, while male athletes are presented solely as athletes (Knight and Giuliano 2001), suggesting that females athletes participating in a male-appropriate sport must challenge traditional gender role stereotypes (Grau et al., 2007). So, based on the arguments regarding source credibility and traditional gender role stereotypes, the following hypothesis us proposed regarding female and male athlete endorsers:

H3: Male athlete endorsers will be associated with clothing and sporting good product types more often than women while women will be associated with diet and exercise and personal care product types more often than men.

McGinnis et al (2003) found that women athletes are posed passively, while men are in active, athletic poses, this was further corroborated by Grau et al. (2007)'s findings female athlete endorsers are suggestively clad, suggesting that female athletes are being chosen based on sex appeal. These studies have however been predominantly based in the USA, however, due to this phenomenon of using female athletes for the sexuality and attractiveness, the following hypothesis are provided in the context of UK female athletes:

H4: For female athletes there will be a greater likelihood that they will be dressed either suggestively, partially clad or posed passively than athletic and active poses while for male athletes there will be a greater likelihood that they will be dressed in athletic and active poses than either suggestively or partially clad.

The UK is described as one of the most diversified countries in the world. Reports by the Equality and Human Rights Commission, an independent statutory body established to help eliminate discrimination, reduce inequality, protect human rights and to build good relations in Britain (Equality and Human Rights Commission (EHRC), 2010) suggest that "Britain is a far more diverse society than it was a generation ago and nearly 1 in 10 British children is growing up in a mixed-race household"., it is expected 
that the protected characteristics under the Equality Act of the UK are fully represented in advertisement as a reflection of the society (Mogaji, 2015a).

The EHRC in UK has identified nine protected grounds for equality of human rights which will form the basis for this research - age, disability, gender reassignment, marriage and civil partnership, pregnancy and maternity, race, religion and beliefs and sex. Among these nine characteristics, race and gender has often been a major concern, and while gender (of athletes), the race of these female athletes endorsing product is also considered an important feature. A minority group within the context of race in UK is BAME, which is used in the UK to refer to people who are not white, predominantly British English African and Afro Caribbean, Asian and minority ethnic groups. Even as Fowler \& Carlson (2015) noted that ethnicity of the models plays a crucial role in the advertisement display, the following hypothesis is proposed:

H5: There are significantly more 'white' female athletes endorsing products in magazine advertising compared to BAME female athletes.

\section{Methodology}

Content Analysis

This study utilised a content analytic method to analyse advertisements in Sport magazine to answer the research questions listed in the previous section. Krippendorff (2004) defined content analysis as "a research technique for making replicable and valid inferences from texts (or other meaningful matter) to the contexts of their use" (p. 18).

Content analysis is considered the most commonly used method of analysis in investigations of sports media and can be considered reliable, based on a certain amount of transparency as the data collected can be re-analysed by another researcher (Crossman, Vincent, and Speed, 2007). To further add to its credibility, Bowen (2009) argued that it is an unobtrusive and non-reactive method, as the documents examined have already been produced and therefore are unaffected by the research process. This method has been used in analysing websites (Goodman,2017) print media advertisements (Czarnecka \& Evans, 2013; Mogaji, 2015a, Mogaji et al, 2018) and even more specifically the study being replicated used same methodology.

Sampling

The content analysis was employed to explore the prevalence of sportswomen in Sport magazine, an award-winning weekly magazine distributed in the UK over a four-year period (2012-2015). 195 issues of the magazine were published within this period (available at https://issuu.com/sportmagazine . The earliest online version for a year period of Sports is from 2012, which suggested the selected timeframe. The magazine was selected because it offers coverage on all sports and does not specifically focus on any one sport in particular. Moreover, it is the most-read sport magazine in the UK, 
published and freely distributed weekly. Sports was first published in September 2006 and now has a circulation of 304,400 (ABC Average Distribution Jan-Jun 2015), a male $93 \%$ audience profile and an $81 \%$ ABC1 audience profile. The average Sport magazine reader has a pre-tax gross income of $£ 60,061$, reflecting the affluent, urbanite nature of its readership (Sports, 2015). The magazine is published every week apart from the first and last week of the year because of the holidays. In total, 196 editions over the four-year period were content analysed.

\section{Coding Framework}

Building on the previous studies which have undertaken content analysis of print media (Mogaji, 2015, Duncan et al.; 1998), a coding sheet was developed. The advertisements were coded, based on the closely related ideas of gender appropriateness as to further gain insight into how brands understand the readership of Sport magazine and how they plan to reach out to them. Male-appropriate advertisements are advertisements for brands, such as men's grooming products (shaving powder, shaving razors, shampoo and men's aftershave). Female-appropriate included brands, such as body creams specifically for women, make-up and perfume, while neutral-appropriate advertisements include cars, mobile contracts and special events.

Coding Procedures

Two coders of different genders, born and raised in the UK, served as the coders for research. They were all independent of each other, not aware of the objective of this research and were offered training, which began with an explanation of the content analysis method and the processes involved. They were offered codebooks with operational definitions of the variables to be identified, and other variables within the coding sheet; this is the guideline recommended by Kolbe and Burnett (1991) and adopted by Taylor et al. (2005).

\section{Reliability}

Krippendorff (2013) argued that valid coding relies greatly on data and instrument reliability and coding subjectivity presents a great concern, as identified by Pate et al. (2014). To test the reliability of the coded advertisement, 520 advertisements were randomly selected to test intercoder reliability for the advertisement analysis, using Cohen's Kappa, ranging from 0.925 to 1.00 , they all reached acceptable reliability levels (Neuendorf, 2002).

\section{Results}

Hypothesis 1-Number of Males vs. Females

3,306 full-page advertisements were analysed to gain insight into the types of products being advertised and athlete endorser being used in the advertisement. During the 
sample period, there were 277 advertisements featuring athlete endorser. $94.9 \%$ of the advertisements $(\mathrm{n}=263)$ exclusively featured a male athlete, $1.4 \%$ of the advertisements $(n=4)$ featured both male and female athlete endorser while $3.6 \%$ of the advertisements $(n=10)$ exclusively featured a female athlete. In terms of frequency of male athletes being used- Joe Hart (38), Michael Phelps (14) and Mark Cavendish (14) were used in 66 advertisements for Head and Shoulders shampoo. Idowu Philips, Ashley Young and Mo Farah featured in 31 advertisements for Lucozade Sports while only seven females were featured in 10 advertisements from the sample. Results from this analysis indicated that female athletes were seldom featured in advertisements compared to their male counterparts; this support the hypothesis that there are significantly more male athletes endorsing products in sports magazine compared to female athletes.

Hypothesis 2-Sport Types

Hypothesis 2 predicts that advertisements featuring female athlete endorsers will come more frequently from individual sports whereas males appearing will be from team sports. The result found support for this hypothesis. Seven female athletes were used as endorsers in sampled advertisements. Jessica Ennis (Athlete) was featured twice for Aviva and once for Vitality, Jenna Randal (Swimmer) was featured once for Next, Lucy Chittenden (Athlete) was featured once for FedEx, Paula Radcliff (Athlete) for Nike, Keri-Anne Payne (Swimming) for Links of London ${ }^{\mathrm{TM}}$ Jewellery, Beth Tweddle (Gymnast) for GSK and Helen Jenkins (Athlete) for Sport Drink. These are four athletes from track and fields, two from Swimming and one from gymnastics, all from individual sport. There were no females from male-appropriate sports like football, cricket or rugby. For the 263 advertisements featuring male athletes, there were 51 different male athletes, in addition there was a football Coach, the Football and Rugby Team. Nine of the male athletes were featured more than five times. $46.3 \%$ of the advertisements $(n=$ 122) featured male athletes from individual sport as endorsers while $53.6 \%$ of the advertisements $(n=141)$ featured male athletes from a team sport as endorsers. This supports the hypothesis that female athletes from individual sport appears more often as endorsers are those from team sport while that male athletes from team sport appears more often as endorsers than those from individual sport.

\section{Hypothesis 3 - Product Type}

Hypothesis 4 stated that male and female athletes would be associated with different product types. For this hypothesis to be supported, there should be more men than women endorsing clothing and sporting goods. This part of the hypothesis was supported. Male athletes were often endorsing grooming products (Gillette razors and electric shavers), technology products (televisions and mobile phones) and Sportswear and accessories (Nike and Adidas) Cars (Vauxhall and Fiat) and Fashion accessories. Female Athletes on the other hand were more endorsing services (Aviva, Vitality and FedEx), Jewelleries and Sportswear. The H3 is therefore partially supported as male 
athlete were endorsing more clothing and sporting good products than the female athletes. Likewise, the female Athletes were not endorsing diet and exercise and personal care product types but instead financial and logistics services albeit they were less frequently used as endorsers.

Hypothesis 4 - Dress type

Hypothesis 4 stated that females would be dressed more suggestively or partially clad than modestly. Of all the 7 advertisements that featured female athletes, 4 featured a female athlete in their active sportswear, another was in a track suit while the other two were not wearing any sports uniform, there was no evidence to suggests that female athletes are sexualised when featured in advertisements. Likewise, the male athletes were often featured in their active wears - Chris Hoys on his bicycle, Joe Hart in his Goal Keeper's Uniform and Mo Farah in his shorts. This hypothesis is therefore not supported, at least in the context of sports advertisements, female athletes are often portrayed in athletic and active poses.

Hypothesis 5 - Athlete Race

It was proposed that there will white' female athletes will significantly be more visible as endorser compared to BAME female athletes. It must be acknowledged that the number of female athletes featured in the whole sample is quite low $(n=7)$ and therefore the comparison between their rave may not be significant, however, the analysis revealed that of all the seven athletes features, Jessica Ennis is the only one that can be considered BAME as her father is from Jamaica. The others are considered British, Keri-Anne Payne and Beth Tweddle were both born in Johannesburg, South Africa, to British parents. Therefore, the hypothesis is deemed supported that white' female athletes will significantly be more visible as endorser compared to BAME female athletes, albeit not significant due to considerable low number of sample.

\section{Discussion}

The analysis of advertised brands in the magazine provides greater detail on how brands associate their products with a specific gender. This adds another dimension in further understanding the under-representation and lack of brand endorsement for female athletes, which should of great concern for sports' managers, brand managers and even academia.

This study replicates and extends Grau et al. (2007)'s previous work on the frequency and nature of portrayals of female athlete endorsers in magazine advertisements. This replication was successfully done, and it further adds credibility to their study. In comparison with was reported in the USA about ten years ago, no much progress has been achieved. Grau et al. (2007) found that $12.4 \%$ of the sample contained female athletes (either alone or with males) meanwhile, in UK, as at the time of data collection 
and analysis, $5 \%(n=14)$ of UK sports advertisement featured contained female athletes (either alone or with males). This further suggests that female American athletes had greater chances than their UK counterpart since 10 years ago, and even now, they are still not catching up, female American athletes have better chances of being a brand endorser than their UK counterpart. There were no females from male-appropriate sports like football, cricket or rugby, suggesting that brands may not consider female athletes a worthwhile vehicle to carry their brand message and reach out to consumers in male-dominated sports.

Furthermore, Grau et al. (2007) revealed that female athletes in individual sports are often featured more than female athletes in team sports, this was also the same in the UK, however on a closer look, $75 \%$ of the portrayals for female athletes were in individual sports, while just four (25\%) were in team sports, suggesting that team sports female athletes still has a glimpse of hope and opportunity, this is however not in the case in UK, all the female athletes featured in the advertisements were from individual sports, there was no one from a team sports.

While considering the Hypothesis 3 around product type, the hypothesis was not fully supported as the few female athletes that were being used worked with brands which are diet and exercise and personal care product types as hypothesised. Like Grau et al. (2007) found, there was no female athletes endorsing for cosmetics and personal care, perhaps norming the society's expectations around the brand congruency between a female athletes and beauty products as it was noted that professional models were used to model these cosmetics and personal care instead of the female athletes themselves.

In addition, these findings around the product products being advertised in sports media, it further highlights the idea that sport is still aimed at men, whereas women, for some reason, are not yet invited as there were no advertisements for female-targeted products. All the advertisements were predominantly products men are far more likely to show an interest in. Gillette, Head \& Shoulders, Nivea, Regaine, Dove and Loreal all advertised products which were specifically for men, even though these very same brands make products for women as well. Wouldn't it be nice to see an advertisement for a femaleoriented product in a sports' magazine?

The presence of sportsmen endorsing products was also observed during the analysis of the advertisements: Sebastian Vettel endorsed Braun Electric Shavers; and Rafael Nadal modelled for Tommy Hilfiger underwear; while Tony Parker and Novak Djokovic modelled wristwatches. Female brand ambassadors were evidently absent, even for products which were gender-neutral, such as wristwatches. Lucozade Sport can also be challenged for featuring no female athletes on their advertisements, even though they had 31 advertisements in the magazine. It would be encouraging to see a female athlete on an advertisement, as the drinks are for everyone involved in sports and not just for men. 
It must be acknowledged that the media and the brands are for-profit entities and they are more interested in increasing profit by meeting the needs and interest of fans. It is, therefore, understandable that brands will want to be associated with more successful and appealing athletes as it would increase brand equity. However, considerable effort should be made to ensure equal opportunities for both genders, to encourage more people get involved with sport and have individuals they look up to.

With regards to the dress types as presented in hypothesis 4, UK female athletes were often better presented, their athletic capabilities were represented. Grau et al. (2007) found that $81 \%$ of the female athletes featured in their sample were as classified suggestively dressed and partially nude with $19 \%$ presented in passive and active participation in sports. On this note, UK advertisers made effort not to sexualise the female athletes but highlight the active participation in sports.

The race of the female athletes was also considered, which suggest an additional hurdle for a BAME athletes to become a brand ambassador. This was not considered in Grau et al. (2007)'s study but it further highlights the challenges of a BAME female athletes in a team sports - for example Eniola Aluko, the Chelsea and England international footballer. They must compete with other 'white' female athletes, other female athletes in individual sports and even more challenging, compete with men to become a brand ambassador.

\section{Conclusion}

This study set out to replicate the study of Grau et al. (2007)'s study carried out over ten years ago in the United States of America with the aim of examining the frequency and nature of portrayals of female athlete endorsers in UK Sports magazine. It is unfortunate that this study was not able to add anything more positive to the data available regarding the portrayal of women in sport; the findings suggest that female athletes are still significantly underrepresented in quantity and misrepresented in the quality of brand endorsements, they are less likely to receive brand endorsements unlike their male counterparts.

Broadly speaking, these findings add new knowledge to how the gender is represented in the media and specifically in advertising. By having a comparison with the US and over a period to establish if there has been an improvement. Findings indicates that US female athletes are still better chanced to endorse brands, they have been having a better opportunity since the last ten years but notwithstanding, it is considered low for female athletes across both countries.

Theoretically, this study makes some key contributions. Firstly, it was able to replicate the study of Grau et al. (2007) which further adds credibility to their research proves and findings. Secondly, it offered a cross-country insight into frequency and nature of portrayals of female athlete endorsers in advertisements, Thirdly, it opens further 
avenue for research, especially the race of female athletes which has not been previously explored and lastly, much of the research on portrayal in recent years has focused solely on the portrayal and underrepresentation of women in sport, the study presents an additional insight through advertisements placed in the magazine, presenting sports as a man's world - advertising products men are more likely to use.

This study has significant managerial and practical implications. Sports Talent Agency has got the responsibility to position their clients in a positive light, make them visible and appealing to prospective brand managers for endorsements. From a business point of view, the athletes must be able to convey their story, showcase their brand identifies as an individual and engage with the brands' target audience. As earlier suggested, BAME athletes, especially those in team sports, have to recognise will have to recognise their challenges and make effort to overcome it.

Brand Managers will have to make conscious creative decisions to reach out to more female athletes to endorse their products, BAME female athletes as well. This may not be a good business decision, as brand managers may argue they are not appealing to their target audience, but it should be considered form of equal opportunity for everyone. Athletes should be given opportunities irrespective of their race or gender. The female athletes will be very much suitable in reaching out to a different and additional market that may not have been covered by a male athlete. Brand managers should, therefore, make sure that their advertisements reflect as much demography of their target market as possible.

It is important also to increase the public's interest in women's sport, get more media coverage and female athletes taking ownership of their brands. Further research can explore the challenges of female athletes in becoming brand ambassadors - perhaps understanding their experiences, the brand managers' perception about female athletes and the general public perception, thereafter developing initiatives to enhance the commercial viability of sportswomen.

As with any other study, this research had some limitations and the findings should therefore be interpreted in relation to these limitations. The study confined itself to the analysis of UK newspapers, and though it used a comparatively large sample of advertisements spread over different times of the year, the question of the representativeness of the sample for the country is always debatable, affecting the generalisability of the result. Sport is considered the only neutral sports' magazine published and freely distributed weekly in the UK. Unlike Sports Illustrated, which has been published for a longer period, the sample size is quite limited for Sports. However, considerable effort was made to collect a large amount of data for the analysis. 
Note

1. Since data was last collected in December 2015, Sports Magazine closes after ten years in February 2017, the magazine has previously ceased publication briefly in 2009 following the collapse of its French parent company, Sport Media \& Strategie, it was bought by Wireless Group and it celebrated its tenth anniversary in September 2016. There is no indication of a new owner yet.

2. A review of the magazine in 2016 just before and after the Olympics/ Paralympics games reveals an increased in brands supporting the female athletes but not necessarily as brand endorsers.

- Katarina Johnson-Thomson for Nissan in her Great Britain athletic vest,

- Laura Troth as DFS Team GB Ambassador in her activewear as a Cyclist

- Jessica Ennis -Hill (Heptathlete) and Lizzie Armitstead (Cyclist) being wished best of luck by BP

- Elinor Barker, Cyclist in her active gear declared a team Visa Ambassador

- Jessica Ennis -Hill (Heptathlete) and Lizzie Armitstead (Cyclist) were congratulated for their successful outing at the Olympics games by BP.

- Great Britain Women's Hockey Team (featuring 3 players in active pose) were congratulated by Investec

- Laura Troth was also congratulated by DFS.

- Stef Reid was wished best of luck at the Paralympics games by BP

- Eleanor May Simmonds, British Paralympian swimmer on Channel 4 advertising the broadcast of the Paralympic games

- Stef Reid was congratulated for a successful outing at the Paralympics games by BP.

3. With regards to BAME female athletes in team sports, there has been some progress. In 2016, Chelsea's Eniola Aluko became Under Armour's first female athlete in the UK, in 2017, she was picked by Sally Hansen as their global brand ambassador. Likewise, in individual sports for BAME, there has been some progress. In 2017, two times Olympic boxing champion, Nicola Adams became a brand ambassador for Skincare brand E45. 


\section{References}

ARAI, A., KO, Y.J. and ROSS, S., 2014. Branding athletes: Exploration and conceptualization of athlete brand image. Sport Management Review, 17(2), pp. 97 106.

BILLINGS, A.C., 2008. Olympic media: Inside the biggest show on television. Routledge.

BILlingS, A.C., ANGELINI, J.R. and DUKE, A.H., 2010. Gendered profiles of Olympic history: Sportscaster dialogue in the 2008 Beijing Olympics. Journal of Broadcasting \& Electronic Media, 54(1), pp. 9-23.

BISCOMB, K. and GRIGGS, G., 2013. 'A splendid effort!'Print media reporting of England's women's performance in the 2009 Cricket World Cup. International Review for the Sociology of Sport, 48(1), pp. 99-111.

BISHOP, R., 2003. Missing in action Feature Coverage of women's sports in Sports Illustrated. Journal of Sport \& Social Issues, 27(2), pp. 184-194.

BURTON, L.J., 2015. Underrepresentation of women in sport leadership: A review of research. Sport Management Review, 18(2), pp. 155-165.

CARTER, J.A., CASANOVA, E. and MAUME, D.J., 2015. Gendering Olympians: Olympic Media Guide Profiles of Men and Women Athletes. Sociology of Sport Journal, 32(3), pp. 312-331.

COAKLEY, J.J. and PIKE, E., 2009. Sport in society: Issues and controversies. 10th edn. New York, NY: McGraw-Hill.

COCHE, R., 2013. Is ESPN really the women's sports network? A content analysis of ESPN's internet coverage of the Australian open. Electronic News, 7(2), pp. 72-88.

COOKY, C., MESSNER, M.A. and HEXTRUM, R.H., 2013. Women play sport, but not on TV a longitudinal study of televised news media. Communication \& Sport, 1(3), pp. 203-230.

COPELAND, R., FRISBY, W. and MCCARVILLE, R., 1996. Understanding the sport sponsorship process from a corporate perspective. Journal of Sport Management, 10, pp. $32-48$.

CROssman, J., VINCENT, J. and SPEED, H., 2007. The Times They are AChangin'Gender Comparisons in Three National Newspapers of the 2004 Wimbledon Championships. International Review for the Sociology of sport, 42(1), pp. 27-41.

EAGLY, A.H., 1987. Sex differences in social behavior: A social-role interpretation. Psychology Press. 
EAGLY, A.H. and KARAU, S.J., 2002. Role congruity theory of prejudice toward female leaders. Psychological review, 109(3), pp. 573.

EAGLY, A.H. and WOOD, W., 1991. Explaining sex differences in social behavior: A meta-analytic perspective. Personality and Social Psychology Bulletin, 17(3), pp. 306315.

FINK, J.S., 2014. Female athletes, women's sport, and the sport media commercial complex: Have we really "come a long way, baby"? Sport Management Review, .

FINK, J.S., PARKER, H.M., CUNNINGHAM, G.B. and CUNEEN, J., 2012. Female athlete endorsers: Determinants of effectiveness. Sport Management Review, 15(1), pp. 13-22.

FORTUNATO, J.A., 2001. Public relations strategies for creating mass media content: A case study of the National Basketball Association. Public Relations Review, 26(4), pp. 481-497.

FOWLER, J.G. AND CARLSON, L., 2015. The visual presentation of beauty in transnational fashion magazine advertisements. Journal of Current Issues \& Research in Advertising, 36(2), pp.136-156.

FRANKE, G.R., CROWN, D.F. and SPAKE, D.F., 1997. Gender Differences in Ethical Perceptions of Business Practices: A Social Role Theory Perspective. Journal of Applied Psychology, 82(6), pp. 920-934.

FULLERTON, S., 2006. Sports marketing. McGraw-Hill/Irwin.

GEURIN-EAGLEMAN, A.N. and BURCH, L.M., 2015. Communicating via photographs: A gendered analysis of Olympic athletes' visual self-presentation on Instagram. Sport Management Review,

GITLIN, T., 1980. The whole world is watching: Mass media in the making \& unmaking of the new left. Univ of California Press.

GODOY-PRESSLAND, A., 2014. 'Nothing to report': a semi-longitudinal investigation of the print media coverage of sportswomen in British Sunday newspapers. Media, Culture \& Society, pp. 0163443714532977.

GOODMAN, J.R., 2017. Best Practices or Advertising Hype? A Content Analysis of Cosmetic Surgery Websites' Procedural, Risk, and Benefit Information. Journal of Current Issues \& Research in Advertising, 38(2), pp.146-164.

GRAM, M., 2004. The future world champions? Ideals for upbringing represented in contemporary European advertisements. Childhood, 11(3), pp.319-337. 
GRAU, S.L., ROSELLI, G. AND TAYLOR, C.R., 2007. Where's Tamika Catchings? A content analysis of female athlete endorsers in magazine advertisements. Journal of Current Issues \& Research in Advertising, 29(1), pp.55-65.

GREER, J.D., HARDIN, M. and HOMAN, C., 2009. "Naturally" less exciting? Visual production of men's and women's track and field coverage during the 2004 Olympics. Journal of Broadcasting \& Electronic Media, 53(2), pp. 173-189.

GWINNER, K. and SWANSON, S.R., 2003. A model of fan identification: Antecedents and sponsorship outcomes. Journal of services marketing, 17(3), pp. 275-294.

HALLMANN, K., 2012. Women's 2011 Football World Cup: The impact of perceived images of women's soccer and the World Cup 2011 on interest in attending matches. Sport Management Review, 15(1), pp. 33-42.

HARDIN, M., 2005. Stopped at the gate: Women's sports, "reader interest," and decision making by editors. Journalism \& Mass Communication Quarterly, 82(1), pp. 62-77.

HARDIN, M. and GREER, J.D., 2009. The influence of gender-role socialization, media use and sports participation on perceptions of gender-appropriate sports. Journal of Sport Behavior, 32(2), pp. 207.

HARDIN, M., LYNN, S. and WALSDORF, K., 2005. Challenge and conformity on "contested terrain": Images of women in four women's sport/fitness magazines. Sex Roles, 53(1-2), pp. 105-117.

HEILMAN, M.E., 2001. Description and prescription: How gender stereotypes prevent women's ascent up the organizational ladder. Journal of Social Issues, 57(4), pp. 657 674 .

JAMES, J.D., 2011. Attitude toward advertising through sport: A theoretical framework. Sport Management Review, 14(1), pp. 33-41.

JONES, D., 2013. Online coverage of the 2008 Olympic Games on the ABC, BBC, CBC and TVNZ. Pacific Journalism Review, 19(1), pp. 244.

KANE, M.J., 2013. The better sportswomen get, the more the media ignore them. Communication \& Sport, 1(3), pp. 231-236.

KANE, M.J., 1988. The female athletic role as a status determinant within the social systems of high school adolescents. Adolescence, 23(90), pp. 253.

KIAN, E.M., VINCENT, J. and MONDELLO, M., 2008. Masculine hegemonic hoops: An analysis of media coverage of March Madness. Sociology of Sport Journal, 25(2), pp. 223. 
KIAN, E.T.M., MONDELLO, M. and VINCENT, J., 2009. ESPN-The women's sports network? A content analysis of Internet coverage of March Madness. Journal of Broadcasting \& Electronic Media, 53(3), pp. 477-495.

KINKEMA, K.M. and HARRIS, J.C., 1998. MediaSport studies: Key research and emerging issues. In: L.A. WENNER, ed, Media Sport. London, England: Routledge, pp. $27-54$.

KOIVULA, N., 2001. Perceived characteristics of sports categorized as gender-neutral, feminine and masculine. Journal of Sport Behaviour, 24(4), pp. 377-393.

KOIVULA, N., 1995. Ratings of gender appropriateness of sports participation: Effects of gender-based schematic processing. Sex Roles, 33(7-8), pp. 543-557.

KROPP, F., LAVACK, A.M., HOLDEN, S.J. and DALAKAS, V., 1999. Attitudes toward beer and tobacco sports sponsorships. Sport Marketing Quarterly, 8, pp. 49-58.

LUMPKIN, A., 2009. Female representation in feature articles published by Sports Illustrated in the 1990s. Women in Sport \& Physical Activity Journal, 18(2), pp. 38.

MESSNER, M.A., 2009. It's all for the kids: Gender, families, and youth sports. Univ of California Press.

MESSNER, M.A., 2002. Taking the field: Women, men, and sports. U of Minnesota Press.

MOGAJI, E., BADEJO, A. \& CHARLES, S., 2018. Sportswomen as Brand Ambassadors: Prospects, Challenges and Possibilities, London: Sportswomen Project.

MOGAJI, E., CZARNECKA, B. AND DANBURY, A., 2018. Emotional appeals in UK business-to-business financial services advertisements. International Journal of Bank Marketing, 36(1), pp.208-227.

MOGAJI, E., 2015a. Reflecting a diversified country: A content analysis of newspaper advertisements in Great Britain. Marketing Intelligence \& Planning, 33(6), pp.908-926.

MOGAJI, E., 2015b. Portraying the Female Gender in Sports: Progression or Regression? Conference Proceedings of British Sociological Association (BSA) Annual Conference at Glasgow Caledonian University, Glasgow, Scotland

MULLIN, B.J., HARDY, S. and SUTTON, W., 2014. Sport Marketing 4th Edition. Human Kinetics.

OBEL, C., 1996. Collapsing Gender in Competitive Bodybuilding Researching Contradictions and Ambiguity in Sport. International review for the sociology of sport, 31(2), pp. 185-202. 
PAN, Z. and KOSICKI, G.M., 1993. Framing analysis: An approach to news discourse. Political communication, 10(1), pp. 55-75.

PEDERSEN, P.M., MILOCH, K.S. and LAUCELLA, P.C., 2007. Strategic sport communication. Human Kinetics.

PRATT, J., GRAPPENDORF, K., GRUNDVIG, A. and LEBLANC, G., 2008. Gender differences in print media coverage of the 2004 summer Olympics in Athens, Greece. Women in Sport \& Physical Activity Journal, 17(2), pp. 34.

REIN, I., KOTLER, P. and SHIELDS, B.R., 2006. The elusive fan: Reinventing sports in a crowded marketplace. McGraw Hill Professional.

THOMSON, M., 2006. Human brands: Investigating antecedents to consumers' strong attachments to celebrities. Journal of Marketing, 70(3), pp. 104-119.

TILL, B.D., 2001. Managing athlete endorser image: The effect of endorsed product. Sport Marketing Quarterly, 10(1), pp. 35-43.

VAN RIPER, T. and BADENHAUSEN, K., July 22nd, 2008-last update, Top earning female athletes. Available: http://www.forbes.com/2008/07/22/women-athletesendorsements-biz-sports-cx_tvr_kb_0722athletes.html [January 15th, 2015].

WEBER, J.D. and CARINI, R.M., 2012. Where are the female athletes in Sports Illustrated? A content analysis of covers (2000-2011). International Review for the Sociology of Sport, , pp. 1012690211434230.

WEIGHT, E.A. and COOPER, C.G., 2015. Framing the Industry. Journal of Applied Sport Management, 7(4), pp. 57-83.

WHANNEL, G., 1992. Fields in vision: Television sport and cultural transformation. London, England: Routledge.

ZHANG, J.J., LAM, E.T., CIANFRONE, B.A., ZAPALAC, R.K., HOLLAND, S. and WILLIAMSON, D.P., 2011. An importance-performance analysis of media activities associated with WNBA game consumption. Sport Management Review, 14(1), pp. 6478. 